\title{
The Construction of Social Services of the Evaluation Index about the Colleges and Universities
}

\author{
Feng lu ${ }^{1, a}$, Shang Yun long ${ }^{2, b}$ and Zheng Kangning ${ }^{3, c}$ \\ ${ }^{1,2,3}$ Beijing City University, China \\ a,b,c fenglu@bcu.edu.cn
}

Keywords: social service; balanced scorecard; colleges and universities

Abstract. This article uses the balanced score card (BSC) and various analysis method construct the evaluation index system of social services.Based on the BSC to build model, using factor analysis, descriptive analysis, hierarchical analysis method, it is used in study of higher education school of social service function of performance measurement. This article hopes to find a unified standard in China's colleges and universities social service evaluation index method, to improve and popularize this method.

\section{Introduction}

In the mid nineteenth Century to late nineteenth Century, colleges and universities from the beginning with the society is not only a state of scientific research, and gradually become the state of cooperation between universities and colleges. From 20th century to now, the higher education schools in addition to teach students, two important professional scientific research ability, Higher education for the social service of the college of vocational ability has become the third indispensable professional higher education school ability is accepted by the countries of all classes. It as an integral part of development of higher education schools continue to catalyst ${ }^{[1]}$.

This article uses the balanced score card (BSC) and various analysis method construct the evaluation index system of social services. The balanced scorecard from finance, customer, internal business, learning and growth four Angle, to the organization's strategic implementation for operational metrics and the target of a new performance management system. Based on the BSC to build model, using factor analysis, descriptive analysis, hierarchical analysis method, it is used in study of higher education school of social service function of performance measurement. This article hopes to find a unified standard in China's colleges and universities social service evaluation index method, to improve and popularize this method.

\section{Research method}

\section{1 the questionnaire design and data collection}

Questionnaire survey method is used for the survey data, to select the R and $\mathrm{T}$ two schools questionnaires on network platform to carry out the investigation and research. In order to ensure the reliability of the results and objectivity, the research objects to choose teachers for the teaching and administrative staff, degree in bachelor or above.

The questionnaire content is divided into four parts. Questionnaire using five scales to carry on the design, lists the BSC method respectively the four angles of evaluation index, followed by the customer dimension six indicators, internal operational dimension 8 indexes, learning and growth dimension seven indicators, the financial dimension four indicators. All the indicators of this study is to use positive score, the importance of indicators gradually increased from 1 to 5 points. In $\mathrm{R}$ and $\mathrm{T}$ two school network questionnaire, each school network questionnaire 110, recycling network questionnaire 209, remove unqualified network questionnaire 4, finally have actual effect of network questionnaire 205, including $104 \mathrm{R}$ school, $101 \mathrm{~T}$ school, network questionnaire actual recovery was $93.18 \%$. 


\section{2 data analysis method}

Descriptive analysis was conducted on data summarized, and its characteristic analysis. This method is mainly related to the concentration of data trend analysis, discrete degree analysis, etc ${ }^{[2]}$.

Reliability refers to the reliability of measurement data, and general use Crch's Alpa coefficient as a measure of the reliability of evaluation index. Cronbach's Alpha coefficient values within the zero and one, the closer the said was the higher the reliability of the test data. As long as it is generally believed that Crch value of zero point seven zero is generally reliable, belong to high reliability interval between zero point seven zero and zero point three five, while less than zero point three five for the low reliability, it is not reliable[错误!未定义书签。].

Factor analysis is also called the validity analysis, factor analysis is to study how to use the least amount of information loss will many of the original variables are condensed into a few factors, and makes the factor has certain named explanatory method of multivariate statistical analysis[错误!未定 义书签。].

Hierarchical analysis method is used to more standard, the multi-objective decision of a systematic $\operatorname{method}^{[3]}$.

Independent sample $\mathrm{T}$ test two samples were randomly selected from a certain number of observation object, the measuring index of a comparison, concluded that two independent sample population mean whether there is obvious difference[错误!未定义书签。].

\section{Based on the BSC model in constructing evaluation index system of social service in colleges and universities}

\section{1 the questionnaire descriptive analysis}

\subsection{1 basic information analysis}

Descriptive analysis of the basic information of the people surveyed, measured the crowd to see the actual distribution.

Table 1 Respondents basic information descriptive statistics

\begin{tabular}{cccc}
\hline Basic & information & classification & frequency \\
\hline \multirow{2}{*}{ Male } & male & 103 & 50.2 \\
& female & 102 & 49.8 \\
Education & Undergraduate course & 53 & 25.9 \\
background & Master's degree & 98 & 47.8 \\
& Doctor's degree & 54 & 26.3 \\
& Teacher & 70 & 34.1 \\
professional & Administrative & & \\
& personnel in colleges & 135 & 65.9 \\
& and universities & & 30.7 \\
Average & The following 1 year & 63 & 26.8 \\
education years & 1-5 years & 55 & 20.0 \\
& 5-10 years & 41 & 22.4 \\
\hline
\end{tabular}

\subsection{2 all indicators of descriptive analysis}


The study samples from four angles for respondents index descriptive qualitative analyses, we from the point of the research results, the four angles of all survey index average than the big three, the conclusion shows that all survey data index has its important place.

Table 2 The four dimensions of each index of descriptive statistics

\begin{tabular}{|c|c|c|c|c|c|c|c|}
\hline Number & index & minimum & maximum & average & $\begin{array}{l}\text { standard } \\
\text { deviation } \\
\end{array}$ & skewness & kurtosis \\
\hline a1 & Customer & 2 & 5 & 3.09 & 0.68 & 0.17 & -0.13 \\
\hline $\mathrm{a} 2$ & Customer & 2 & 5 & 3.26 & 0.73 & 0.11 & -0.26 \\
\hline $\mathrm{a} 3$ & Customer & 2 & 5 & 3.33 & 0.75 & 0.22 & -0.19 \\
\hline $\mathrm{a} 4$ & Awareness & 1 & 5 & 3.38 & 0.84 & 0.08 & -0.33 \\
\hline a5 & Activity propaganda & 1 & 5 & 3.27 & 0.76 & 0.03 & -0.11 \\
\hline a6 & $\begin{array}{c}\text { Respected degree of } \\
\text { service activities }\end{array}$ & 2 & 5 & 3.57 & 0.81 & 0.05 & -0.51 \\
\hline b1 & Students graduate & 2 & 5 & 3.55 & 0.81 & -0.29 & -0.40 \\
\hline $\mathrm{b} 2$ & Course quality & 2 & 5 & 3.50 & 0.81 & -0.26 & -0.46 \\
\hline b3 & Teaching faculty & 2 & 5 & 3.51 & 0.83 & -0.20 & -0.51 \\
\hline b4 & $\begin{array}{l}\text { Scientific research and } \\
\text { social returns }\end{array}$ & 3 & 5 & 3.82 & 0.64 & 0.18 & -0.64 \\
\hline b5 & $\begin{array}{c}\text { Scientific research } \\
\text { achievements conversion } \\
\text { rate }\end{array}$ & 2 & 5 & 3.53 & 0.81 & 0.04 & -0.47 \\
\hline b6 & Between research center & 2 & 5 & 3.58 & 0.85 & 0.01 & -0.63 \\
\hline b7 & Infrastructure utilization & 3 & 5 & 3.78 & 0.62 & 0.20 & -0.58 \\
\hline $\mathrm{b} 8$ & $\begin{array}{l}\text { To participate in social } \\
\text { service rate }\end{array}$ & 3 & 5 & 3.86 & 0.61 & 0.09 & -0.41 \\
\hline $\mathrm{c} 1$ & $\begin{array}{l}\text { Teachers and students } \\
\text { staff satisfaction }\end{array}$ & 2 & 5 & 3.50 & 0.80 & -0.24 & -0.45 \\
\hline $\mathrm{c} 2$ & $\begin{array}{l}\text { The construction of } \\
\text { campus culture }\end{array}$ & 2 & 5 & 3.51 & 0.83 & -0.13 & -0.52 \\
\hline $\mathrm{c} 3$ & Incentive mechanism & 2 & 5 & 3.52 & 0.83 & -0.23 & -0.50 \\
\hline $\mathrm{c} 4$ & Information openness & 1 & 5 & 3.49 & 0.91 & 0.00 & -0.59 \\
\hline $\mathrm{c} 5$ & $\begin{array}{l}\text { Campus information } \\
\text { management system }\end{array}$ & 1 & 5 & 3.54 & 0.97 & -0.22 & -0.37 \\
\hline c6 & $\begin{array}{l}\text { Communication } \\
\text { efficiency }\end{array}$ & 1 & 5 & 3.52 & 0.96 & -0.20 & -0.48 \\
\hline $\mathrm{c} 7$ & Administrative efficiency & 1 & 5 & 3.32 & 0.91 & -0.17 & -0.19 \\
\hline $\mathrm{d} 1$ & Social services budget & 3 & 5 & 3.92 & 0.64 & 0.07 & -0.53 \\
\hline
\end{tabular}




\begin{tabular}{|c|c|c|c|c|c|c|c|}
\hline & year growth rate & & & & & & \\
\hline $\mathrm{d} 2$ & Training cost per head & 3 & 5 & 3.90 & 0.61 & 0.05 & -0.30 \\
\hline d3 & $\begin{array}{l}\text { Social services use fund } \\
\text { annual growth rate }\end{array}$ & 3 & 5 & 3.92 & 0.59 & 0.02 & -0.16 \\
\hline $\mathrm{d} 4$ & $\begin{array}{l}\text { Social services budget and } \\
\text { the annual budget }\end{array}$ & 2 & 5 & 3.87 & 0.61 & -0.06 & -0.03 \\
\hline
\end{tabular}

\subsection{3 scale reliability analysis}

Table 3 Reliability analysis

\begin{tabular}{|c|c|c|c|}
\hline \multicolumn{2}{|c|}{ The dimension } & Cronbach's Alpha & $\mathrm{N}$ of Items \\
\hline \multirow{3}{*}{ The customer dimension } & $\begin{array}{l}\text { The audience's } \\
\text { satisfaction }\end{array}$ & 0.810 & 3 \\
\hline & External effect & 0.800 & 3 \\
\hline & Total & 0.762 & 6 \\
\hline \multirow{4}{*}{$\begin{array}{l}\text { Internal operational } \\
\text { dimension }\end{array}$} & Knowledge service & 0.905 & 3 \\
\hline & $\begin{array}{c}\text { Scientific research } \\
\text { and service }\end{array}$ & 0.753 & 2 \\
\hline & $\begin{array}{c}\text { Direct social } \\
\text { services }\end{array}$ & 0.821 & 3 \\
\hline & Total & 0.791 & 8 \\
\hline Learning and growth & $\begin{array}{c}\text { The organization } \\
\text { construction }\end{array}$ & 0.903 & 3 \\
\hline \multirow[t]{2}{*}{ dimension } & Information capital & 0.821 & 4 \\
\hline & Total & 0.773 & 7 \\
\hline The financial dimension & Total & 0.917 & 4 \\
\hline
\end{tabular}

The table 3 shows that the four dimensions of Cronbach's Alpha coefficient value is greater than 0.7 , indicating the dimensions meet the requirement of reliability test, and high credibility.

\subsection{4 scale validity analysis}

\subsubsection{KMO (Kaiser - Meyer - Olkin) test}

KMO value between zero and one, the closer it gets to the one, which means that the simple correlation coefficient between the variables have square sum of squares, far more than partial correlation coefficient can do factor analysis. It is generally believed $\mathrm{KMO}>0.9$, very suitable for; 0.8 $<\mathrm{KMO}<0.9$, suitable for; $0.7<\mathrm{KMO}<0.8$, general; $0.6<\mathrm{KMO}<0.7$, is not suitable for; $\mathrm{KMO}<$ 0.5 , is not suitable for.

\subsubsection{2 bartlett ball test}


Bartlett spherical test statistics are based on correlation coefficient matrix determinant. If the value is bigger, and the corresponding correlation probability value less than the significance level of the user to specify, then it should be rejected the null hypothesis $\mathrm{H} 0$, thought correlation coefficients could not be unit matrix, the correlation between the original variables.

\subsubsection{3 validity analysis of the customer dimension}

(1) KMO and Bartlett's test

Table 4 KMO and Bartlett's test

\begin{tabular}{|c|c|c|}
\hline $\begin{array}{r}\text { Sampling enough de } \\
\text { Olkin m }\end{array}$ & $\begin{array}{l}\text { s of Kaiser - Meyer - } \\
\text { rements. }\end{array}$ & 0.714 \\
\hline \multirow{3}{*}{ Bartlett sphericity test } & $\begin{array}{c}\text { The approximate } \\
\text { chi-square }\end{array}$ & 448.754 \\
\hline & $\mathrm{df}$ & 15 \\
\hline & Sig. & 0.000 \\
\hline
\end{tabular}

This table shows that the value attribute scale KMO $=0.714$, greater than 0.7 , Bartlett statistic was $448.754, \mathrm{P}=0.000$, $\mathrm{P}$ value is less than 0.01 , shows that customer dimension of selected indicators for exploratory factor analysis.

\section{(2)structural common factor}

\begin{tabular}{|c|c|c|c|c|c|c|c|c|c|}
\hline \multirow{2}{*}{$\begin{array}{l}\text { elem } \\
\text { ent } s\end{array}$} & \multicolumn{3}{|c|}{ The initial eigenvalue } & \multicolumn{3}{|c|}{$\begin{array}{c}\text { Extraction of sum of squares } \\
\text { loaded }\end{array}$} & \multicolumn{3}{|c|}{$\begin{array}{c}\text { Rotate the sum of squares } \\
\text { loaded }\end{array}$} \\
\hline & total & $\begin{array}{c}\text { Variance } \\
\% \\
\end{array}$ & $\begin{array}{l}\text { cumulati } \\
\text { ve } \%\end{array}$ & total & Variance $\%$ & $\begin{array}{l}\text { cumula } \\
\text { tive } \%\end{array}$ & total & $\begin{array}{l}\text { Variance } \\
\%\end{array}$ & $\begin{array}{l}\text { cumulati } \\
\text { ve } \%\end{array}$ \\
\hline 1 & 2.753 & 45.889 & 45.889 & 2.753 & 45.889 & 45.889 & 2.191 & 36.514 & 36.514 \\
\hline 2 & 1.617 & 26.953 & 72.841 & 1.617 & 26.953 & 72.841 & 2.180 & 36.328 & 72.841 \\
\hline 3 & 0.550 & 9.173 & 82.014 & & & & & & \\
\hline 4 & 0.454 & 7.567 & 89.581 & & & & & & \\
\hline 5 & 0.346 & 5.768 & 95.349 & & & & & & \\
\hline 6 & 0.279 & 4.651 & 100.000 & & & & & & \\
\hline
\end{tabular}

Table shows that there are two common factor characteristic root values were greater than 1 , and 2 common factor of the cumulative contribution rate reached $72.841 \%$, shows two common factor can be extracted to response the customer dimension.

\section{(3) factor rotation}

After using the principal component method to extract the common factor, also must be conducted for each practical significance of the common factor reasonable explanation. Rotate the common factor is analyzed by applying the method of maximum variance below.

Table 6 Rotating factor loading

\begin{tabular}{lcc}
\hline & \multicolumn{2}{c}{ element } \\
\cline { 2 - 3 } & 1 & 2 \\
\hline a1 & $\mathbf{0 . 8 4 6}$ & 0.016 \\
a2 & $\mathbf{0 . 8 0 3}$ & 0.232 \\
a3 & $\mathbf{0 . 8 7 7}$ & 0.103 \\
a4 & 0.066 & $\mathbf{0 . 8 2 3}$ \\
a5 & 0.046 & $\mathbf{0 . 9 0 9}$ \\
a6 & 0.233 & $\mathbf{0 . 7 8 2}$ \\
\hline
\end{tabular}


Table shows that common factor 1 (there is major factor loading on a1 - a3, were greater than 0.6 , the reaction is a customer dimension of audience satisfaction attribute; On the common factor in a4-2 a6 has bigger factor loading, were greater than 0.6 , the reaction on the audience dimension of foreign influence attributes.

\subsubsection{4 validity analysis of the internal process dimension}

(1) KMO and Bartlett's test

Table 7 KMO and Bartlett's test

\begin{tabular}{lcc}
\hline \multicolumn{2}{c}{$\begin{array}{c}\text { Sampling enough degrees of Kaiser - Meyer - Olkin } \\
\text { measurements. }\end{array}$} & 0.725 \\
Bartlett sphericity test & The approximate chi-square & 808.102 \\
& df & 28 \\
& Sig. & 0.000 \\
\hline
\end{tabular}

Table shows that value attribute scale $\mathrm{KMO}=0.725$, greater than 0.7 , Bartlett statistic was 808.102 , $\mathrm{P}=0.000, \mathrm{P}$ value is less than 0.01 , shows that the internal process dimension of the selected indicators for exploratory factor analysis.

\section{(2)structural common factor}

Table 8 Explain the total variance

\begin{tabular}{|c|c|c|c|c|c|c|c|c|c|}
\hline \multirow{2}{*}{$\begin{array}{l}\text { elem } \\
\text { ent s }\end{array}$} & \multicolumn{3}{|c|}{ The initial eigenvalue } & \multicolumn{3}{|c|}{$\begin{array}{c}\text { Extraction of sum of squares } \\
\text { loaded }\end{array}$} & \multicolumn{3}{|c|}{$\begin{array}{c}\text { Rotate the sum of squares } \\
\text { loaded }\end{array}$} \\
\hline & total & $\begin{array}{c}\text { Variance } \\
\%\end{array}$ & $\begin{array}{l}\text { cumulati } \\
\text { ve } \%\end{array}$ & total & Variance $\%$ & $\begin{array}{l}\text { cumula } \\
\text { tive } \%\end{array}$ & total & $\begin{array}{c}\text { Variance } \\
\%\end{array}$ & $\begin{array}{l}\text { cumulati } \\
\text { ve } \%\end{array}$ \\
\hline 1 & 3.308 & 41.352 & 41.352 & 3.308 & 41.352 & 41.352 & 2.535 & 31.694 & 31.694 \\
\hline 2 & 1.727 & 21.590 & 62.942 & 1.727 & 21.590 & 62.942 & 2.275 & 28.440 & 60.133 \\
\hline 3 & 1.431 & 17.889 & 80.831 & 1.431 & 17.889 & 80.831 & 1.656 & 20.698 & 80.831 \\
\hline 4 & 0.413 & 5.164 & 85.995 & & & & & & \\
\hline 5 & 0.381 & 4.758 & 90.753 & & & & & & \\
\hline 6 & 0.326 & 4.078 & 94.831 & & & & & & \\
\hline 7 & 0.227 & 2.834 & 97.665 & & & & & & \\
\hline 8 & 0.187 & 2.335 & 100.000 & & & & & & \\
\hline
\end{tabular}

Table shows that there are three common factor characteristic root value were greater than 1 , and 3 common factor of the cumulative contribution rate reached $80.831 \%$, that can be extracted three common factor to reflect the internal process dimension.

\section{(3) factor rotation}

Table 9 Rotating factor loading

\begin{tabular}{cccc}
\hline & \multicolumn{3}{c}{ elements } \\
\cline { 2 - 4 } & 1 & 2 & 3 \\
\hline b1 & $\mathbf{0 . 8 9 0}$ & 0.210 & 0.030 \\
b2 & $\mathbf{0 . 9 2 2}$ & 0.094 & 0.083 \\
b3 & $\mathbf{0 . 8 9 5}$ & 0.082 & 0.165 \\
b4 & 0.015 & 0.154 & $\mathbf{0 . 8 9 0}$ \\
b5 & 0.196 & 0.013 & $\mathbf{0 . 8 8 5}$ \\
b6 & 0.184 & $\mathbf{0 . 8 1 1}$ & 0.212 \\
b7 & 0.112 & $\mathbf{0 . 8 8 8}$ & 0.011 \\
b8 & 0.076 & $\mathbf{0 . 8 6 3}$ & 0.020 \\
\hline
\end{tabular}

For rotating shaft of the factor loading matrix read after analysis, it can be seen: common factor 1 has bigger factor loading on b1-b3, were greater than 0.6 , the reaction is the knowledge of the internal 
process dimension of service attributes; Common factor 2 in b6 - b8larger factor loading, were greater than 0.6 , the reaction is the internal process dimension of direct social service properties; On common factor $3 \mathrm{~b} 4$-b5 have bigger factor loading, were greater than 0.6 , the reaction is the internal process dimension of scientific research and service properties.

\subsubsection{Validity analysis of learning and growth dimension}

\section{(1) KMO and Bartlett's test}

Table $10 \mathrm{KMO}$ and Bartlett's test

\begin{tabular}{lcc}
\hline \multicolumn{2}{c}{$\begin{array}{c}\text { Sampling enough degrees of Kaiser - Meyer - Olkin } \\
\text { measurements. }\end{array}$} & 0.733 \\
\hline \multicolumn{3}{c}{ The approximate chi-square } \\
Bartlett sphericity test & df & 768.231 \\
& Sig. & 21 \\
\hline
\end{tabular}

Table shows that the value of property scale $\mathrm{KMO}=0.733$, greater than 0.7 , Bartlett statistic was $768.231, \mathrm{P}=0.000, \mathrm{P}$ value is less than 0.01 , shows that learning and growth dimension of selected indicators for exploratory factor analysis.

\section{(2)structural common factor}

Table 11 Explain the total variance

\begin{tabular}{|c|c|c|c|c|c|c|c|c|c|}
\hline \multirow{2}{*}{$\begin{array}{l}\text { elem } \\
\text { ent s }\end{array}$} & \multicolumn{3}{|c|}{ The initial eigenvalue } & \multicolumn{3}{|c|}{$\begin{array}{c}\text { Extraction of sum of squares } \\
\text { loaded }\end{array}$} & \multicolumn{3}{|c|}{$\begin{array}{c}\text { Rotate the sum of squares } \\
\text { loaded }\end{array}$} \\
\hline & total & $\begin{array}{c}\text { Variance } \\
\%\end{array}$ & $\begin{array}{l}\text { cumulati } \\
\text { ve } \%\end{array}$ & total & Variance $\%$ & $\begin{array}{l}\text { cumula } \\
\text { tive } \%\end{array}$ & total & $\begin{array}{l}\text { Variance } \\
\%\end{array}$ & $\begin{array}{l}\text { cumulati } \\
\text { ve } \%\end{array}$ \\
\hline 1 & 2.977 & 42.536 & 42.536 & 2.977 & 42.536 & 42.536 & 2.611 & 37.296 & 37.296 \\
\hline 2 & 2.166 & 30.943 & 73.478 & 2.166 & 30.943 & 73.478 & 2.533 & 36.182 & 73.478 \\
\hline 3 & 0.576 & 8.227 & 81.705 & & & & & & \\
\hline 4 & 0.458 & 6.547 & 88.252 & & & & & & \\
\hline 5 & 0.380 & 5.422 & 93.674 & & & & & & \\
\hline 6 & 0.345 & 4.928 & 98.601 & & & & & & \\
\hline 7 & 0.098 & 1.399 & 100.000 & & & & & & \\
\hline
\end{tabular}

Table shows that there are two common factor characteristic root values were greater than 1 , and 2 common factor of the cumulative contribution rate reached $73.478 \%$, two common factor that can be extracted to reflect the dimension to learn and grow.

\section{(3) Factor loading}

Table 13 Factor loading

\begin{tabular}{ccc}
\hline & \multicolumn{2}{c}{ elements } \\
\cline { 3 - 4 } c1 & 1 & $\mathbf{0 . 8 5 8}$ \\
c2 & 0.029 & $\mathbf{0 . 9 5 6}$ \\
c3 & 0.063 & $\mathbf{0 . 9 1 9}$ \\
c4 & 0.126 & 0.030 \\
c5 & $\mathbf{0 . 8 0 3}$ & 0.060 \\
c6 & $\mathbf{0 . 8 6 2}$ & -0.012 \\
c7 & $\mathbf{0 . 8 2 1}$ & 0.188 \\
\hline
\end{tabular}

For rotating shaft of the factor loading matrix read after analysis, it can be seen: common factor 1 have bigger factor loading on $\mathrm{c} 4$ to $\mathrm{c} 7$, were greater than 0.6 , the reaction is dimension information capital attributes to learn and grow; Common factor 2 larger factor loading on c1, c3, were greater than 0.6 , the reaction is dimension attributes of the organization construction to learn and grow. 


\subsubsection{6 validity analysis of the financial dimension}

(1) KMO and Bartlett's test

Table $13 \mathrm{KMO}$ and Bartlett's test

\begin{tabular}{lcc}
\hline \multicolumn{2}{c}{$\begin{array}{c}\text { Sampling enough degrees of Kaiser - Meyer - Olkin } \\
\text { measurements. }\end{array}$} & 0.840 \\
\hline \multicolumn{3}{c}{ The approximate chi-square } \\
Bartlett sphericity test & df & 613.284 \\
& Sig. & 6 \\
\hline
\end{tabular}

The table shows that the financial dimension of $\mathrm{KMO}=0.840$, greater than 0.7 , Bartlett statistic was $613.284, \mathrm{P}=0.000, \mathrm{P}$ value is less than 0.01 , shows that the financial dimension of selected indicators for exploratory factor analysis.

\section{(2)structural common factor}

Table 14 Explain the total variance

\begin{tabular}{|c|c|c|c|c|c|c|}
\hline \multirow[b]{2}{*}{$\begin{array}{c}\text { element } \\
\mathrm{s}\end{array}$} & \multicolumn{3}{|c|}{ The initial eigenvalue } & \multicolumn{3}{|c|}{ Extraction of sum of squares loaded } \\
\hline & total & Variance $\%$ & cumulative \% & total & Variance $\%$ & $\begin{array}{l}\text { cumulative } \\
\%\end{array}$ \\
\hline 1 & 3.210 & 80.245 & 80.245 & 3.210 & 80.245 & 80.245 \\
\hline 2 & 0.377 & 9.417 & 89.662 & & & \\
\hline 3 & 0.263 & 6.567 & 96.230 & & & \\
\hline 4 & 0.151 & 3.770 & 100.000 & & & \\
\hline
\end{tabular}

Table shows that there are a common factor of characteristic root values were greater than 1 , and the common factor of the cumulative contribution rate reached $80.245 \%$, the common factor can response the financial dimension.

\section{(3) Factor loading}

Table 15 Factor loading

\begin{tabular}{lll}
\hline & & elements \\
\cline { 3 - 3 } & & 1 \\
\hline $\mathrm{d} 1$ & 0.848 \\
$\mathrm{~d} 2$ & 0.936 \\
$\mathrm{~d} 3$ & 0.878 \\
$\mathrm{~d} 4$ & 0.919 \\
\hline
\end{tabular}

Since there is only one common factor, no need to factor rotation steps. The chart shows the factor loading of each target values were greater than 0.6 , explain the four indicators can be a good response to the financial dimension.

\section{2 build evaluation index}

\subsection{1 evaluation index is determined}

First using SPSS analysis software after the descriptive analysis on all indicators, you can see the scores of all the indicators are more than three points, that the institute all indicators are set up with a certain degree of importance and rationality. Second in the above after the exploratory factor analysis, this paper will be the original survey indicators as indicators of level 3, then the original indexes after exploratory factor analysis, a three-tier indicators dimension, respectively to extract the comprehensive index as a secondary indicator. Finally, the four angles of the BSC model as the 
primary index, thus established on the basis of the BSC method university social service evaluation index model.

Table 16 University social service evaluation index table

\begin{tabular}{|c|c|c|c|c|c|}
\hline id & $\begin{array}{c}\text { Level } 1 \\
\text { indicators }\end{array}$ & $\mathrm{id}$ & $\begin{array}{c}\text { Level } 2 \\
\text { indicators }\end{array}$ & id & Level 3 indicators \\
\hline \multirow{6}{*}{ A1 } & \multirow{6}{*}{$\begin{array}{c}\text { The } \\
\text { customer } \\
\text { dimension }\end{array}$} & \multirow{4}{*}{ B1 } & \multirow{3}{*}{$\begin{array}{l}\text { The audience's } \\
\text { satisfaction }\end{array}$} & $\mathrm{C} 1$ & Customer satisfaction \\
\hline & & & & $\mathrm{C} 2$ & Customer loyalty \\
\hline & & & & $\mathrm{C} 3$ & Customer recognition \\
\hline & & & \multirow{3}{*}{ External effect } & $\mathrm{C} 4$ & Awareness of colleges and universities \\
\hline & & \multirow[t]{2}{*}{ B2 } & & $\mathrm{C} 5$ & Activity propaganda \\
\hline & & & & C6 & Respected degree of service activities \\
\hline \multirow{8}{*}{ A2 } & \multirow{8}{*}{$\begin{array}{c}\text { Internal } \\
\text { operational } \\
\text { dimension }\end{array}$} & \multirow{3}{*}{ B3 } & \multirow{3}{*}{$\begin{array}{l}\text { Knowledge } \\
\text { service }\end{array}$} & $\mathrm{C} 7$ & Students graduate \\
\hline & & & & $\mathrm{C} 8$ & Course quality \\
\hline & & & & $\mathrm{C} 9$ & Teaching faculty \\
\hline & & \multirow[b]{2}{*}{ B4 } & \multirow{2}{*}{$\begin{array}{l}\text { Scientific } \\
\text { research } \\
\text { service }\end{array}$} & $\mathrm{C} 10$ & Scientific research and social returns \\
\hline & & & & $\mathrm{C} 11$ & $\begin{array}{l}\text { Scientific research achievements } \\
\text { conversion rate }\end{array}$ \\
\hline & & \multirow{3}{*}{ B5 } & \multirow{3}{*}{$\begin{array}{l}\text { Direct social } \\
\text { services }\end{array}$} & $\mathrm{C} 12$ & $\begin{array}{l}\text { The number of school and enterprise } \\
\text { research center }\end{array}$ \\
\hline & & & & $\mathrm{C} 13$ & Infrastructure utilization \\
\hline & & & & $\mathrm{C} 14$ & To participate in social service rate \\
\hline \multirow{7}{*}{ A3 } & \multirow{7}{*}{$\begin{array}{l}\text { Learni } \\
\text { ng and } \\
\text { growth } \\
\text { dimension }\end{array}$} & \multirow{3}{*}{ B6 } & \multirow{4}{*}{$\begin{array}{c}\text { The } \\
\text { organization } \\
\text { construction }\end{array}$} & $\mathrm{C} 15$ & Teachers and students staff satisfaction \\
\hline & & & & $\mathrm{C} 16$ & The construction of campus culture \\
\hline & & & & $\mathrm{C} 17$ & Incentive mechanism \\
\hline & & \multirow{4}{*}{ B7 } & & C18 & Information openness \\
\hline & & & \multirow{3}{*}{$\begin{array}{l}\text { Information } \\
\text { capital }\end{array}$} & C19 & $\begin{array}{c}\text { Campus information management } \\
\text { system }\end{array}$ \\
\hline & & & & $\mathrm{C} 20$ & Communication efficiency \\
\hline & & & & $\mathrm{C} 21$ & Administrative efficiency \\
\hline \multirow{4}{*}{ A4 } & \multirow{4}{*}{$\begin{array}{c}\text { The } \\
\text { financial } \\
\text { dimension }\end{array}$} & \multirow{4}{*}{ B8 } & \multirow{4}{*}{$\begin{array}{l}\text { Sources of } \\
\text { finance }\end{array}$} & $\mathrm{C} 22$ & Social services budget year growth rate \\
\hline & & & & $\mathrm{C} 23$ & Training cost per head \\
\hline & & & & $\mathrm{C} 24$ & $\begin{array}{l}\text { Social services use fund annual growth } \\
\text { rate }\end{array}$ \\
\hline & & & & C25 & $\begin{array}{c}\text { Social services budget and the annual } \\
\text { budget }\end{array}$ \\
\hline
\end{tabular}

\subsubsection{Determine the weight of each index}

\subsubsection{Determine the level 1 of index weight}

Using analytic hierarchy process (ahp), grade level index criterion layer can be obtained by the expert group A corresponding university social service F judgment matrix F - A target layer in the table 17:

Table 17 Judgment matrix F - A

\begin{tabular}{ccccc}
\hline $\mathrm{F}$ & $\mathrm{A} 1$ & $\mathrm{~A} 2$ & $\mathrm{~A} 3$ & $\mathrm{~A} 4$ \\
\hline $\mathrm{A} 1$ & 1 & 2 & 2 & 3 \\
$\mathrm{~A} 2$ & $1 / 2$ & 1 & 2 & 2 \\
$\mathrm{~A} 3$ & $1 / 2$ & $1 / 2$ & 1 & 2 \\
$\mathrm{~A} 4$ & $1 / 3$ & $1 / 2$ & $1 / 2$ & 1 \\
\hline
\end{tabular}


According to the formula

$$
W_{i}=\frac{w_{i}}{\sum_{i=1}^{n} w_{i}}\left(w_{i}=n \sqrt{\prod_{j=1}^{n} a_{i j}}\right)
$$

$(i=1,2, n), n=4$, We can learn the rule layer $\mathrm{u}$ single order results, $\mathrm{W}=\{0.4204 、 0.2686 、 0.1899 、 0.1211\} \mathrm{T}$ 。At the same time we get: the largest eigenvalue of judgment matrix $\lambda \max =\sum_{i=1}^{4} \frac{(A W)_{i}}{4 W_{i}}=4.0680, \mathrm{CI}=\frac{\lambda_{\max }-4}{4-1}=0.0227, \mathrm{n}=4$, $\mathrm{RI}=0.9, \quad \mathrm{CR}=\mathrm{CI} / \mathrm{RI}=0.0252<0.1, \quad$ the judgment matrix F-A satisfactory consistency, so the standard layer of A weight vector Was follows:

Table 18 Level 1 indicators weight

\begin{tabular}{ccc}
\hline id & Level 1 indicators & weight \\
\hline A1 & The customer dimension & 0.4204 \\
A2 & Internal operational dimension & 0.2686 \\
A3 & Learning and growth & 0.1899 \\
A4 & dimension & 0.1211 \\
\hline
\end{tabular}

\subsubsection{Secondary index weight is determined}

According to the factor contribution can be to determine the weight value of the secondary indexes. Table 19 Level 2 indicators weight

\begin{tabular}{ccc}
\hline id & Level 2 indicators & weight \\
\hline B1 & The audience's satisfaction & 0.2020 \\
B2 & External effect & 0.2009 \\
B3 & Knowledge service & 0.1120 \\
B4 & Scientific research service & 0.1005 \\
B5 & Direct social services & 0.0731 \\
B6 & The organization construction & 0.0932 \\
B7 & Information capital & 0.0904 \\
B8 & Sources of finance & 0.1279 \\
\hline
\end{tabular}

\subsubsection{3 weights of level 3 indicators}

Factor analysis was carried out on the index, we get the component score coefficient matrix. Combining with the level 1 and level 2 of the weight of indicators, we get a three-level index weights.

Table 20 Level 3 indicators weight

\begin{tabular}{lcc}
\hline id & Level 3 indicators & weight \\
\hline C1 & Customer satisfaction & 0.0618 \\
C2 & Customer loyalty & 0.0743 \\
C3 & Customer recognition & 0.0702 \\
C4 & Awareness of colleges and universities & 0.0634 \\
C5 & Activity propaganda & 0.0681 \\
C6 & Respected degree of service activities & 0.0726 \\
C7 & Students graduate & 0.0339 \\
C8 & Course quality & 0.0329 \\
C9 & Teaching faculty & 0.0340 \\
C10 & Scientific research and social returns & 0.0297 \\
C11 & Scientific research achievements & 0.0308 \\
C12 & conversion rate & 0.0356 \\
C13 & The number of school and enterprise & 0.0302 \\
\hline
\end{tabular}




\begin{tabular}{lcc}
\hline C14 & To participate in social service rate & 0.0286 \\
C15 & Teachers and students staff satisfaction & 0.0267 \\
C16 & The construction of campus culture & 0.0307 \\
C17 & Incentive mechanism & 0.0315 \\
C18 & Information openness & 0.0253 \\
C19 & Campus information management system & 0.0279 \\
C20 & Communication efficiency & 0.0245 \\
C21 & Administrative efficiency & 0.0276 \\
C22 & Social services budget year growth rate & 0.0330 \\
C23 & Training cost per head & 0.0364 \\
C24 & Social services use fund annual growth & 0.0343 \\
& rate & 0.0358 \\
C25 & Social services budget and the annual & 0.03 \\
\hline
\end{tabular}

\subsubsection{The university evaluation index system of social services}

Table 21 The university social service evaluation index weight

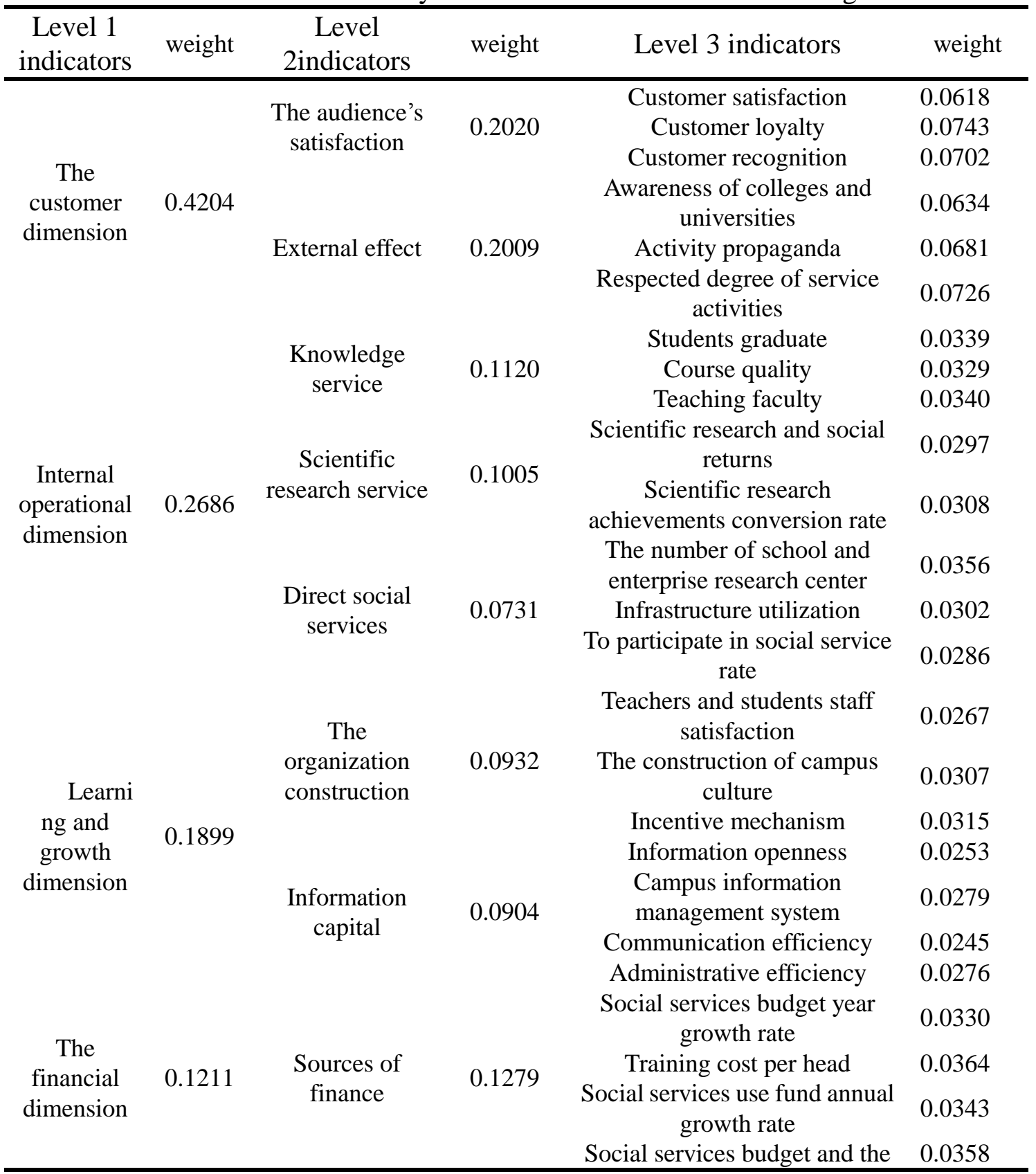




\section{Conclusions}

Based on the BSC to build model, using factor analysis, descriptive analysis, hierarchical analysis method, it is used in study of higher education school of social service function of performance measurement. This article have found a unified standard in China's colleges and universities social service evaluation index method, to improve and popularize this method.

\section{Acknowledgements}

This work was financially supported by The Youth Talent Plan of Beijing High School of Beijing Municipal Education Commission.

\section{References}

[1] ZhuGuoren. From "ivory tower" to "service station" -- a historical review of the evolution of the social service function of Higher Education Institutions.Resarch on Education TSINGHUA University Vol.1 (1999), p.32-38

[2] Xuewei.Statistical analysis and application of SPSS [4th ed.].Renmin University of China press, 2014:p.288-308

[3] CaoMaolin.Analytic Hierarchy Process to Determine the Weight of Evaluation Index and the Calculation of Excel.Jiangsu Science \& Technology Information, Vol.2 (2012), p.39-40 